\title{
Evaluation of the effects, on canopy arthropods, of two agricultural management systems to control pests in olive groves from north-east of Portugal
}

\author{
Sónia A.P. Santos ${ }^{\mathrm{a}, *}$, José A. Pereira ${ }^{\mathrm{a}}$, Laura M. Torres ${ }^{\mathrm{b}}$, António J.A. Nogueira ${ }^{\mathrm{c}}$ \\ ${ }^{a}$ CIMO/Escola Superior Agrária, Instituto Politécnico de Bragança, Apt. 1172, 5301-855 Bragança, Portugal \\ ${ }^{\mathrm{b}}$ Departmento de Protecção de Plantas, Univ. Trás-os-Montes e Alto Douro, 5001-801 Vila Real, Portugal \\ ${ }^{\text {c } C E S A M}$ \& Departamento de Biologia, Universidade de Aveiro Campus de Santiago, 3810-193 Aveiro, Portugal
}

Received 10 May 2006; received in revised form 18 July 2006; accepted 3 September 2006

Available online 13 November 2006

\begin{abstract}
This study aims to investigate the effect of management regime on canopy arthropod community of the olive tree (Olea europaea L.). Field studies were performed in two successive years, 2002 and 2003, in two olive groves, one under organic farming and the other under integrated protection. The integrated protection grove was sprayed once a year in June, with dimethoate, to control the anthophagous generation of the olive moth, Prays oleae (Bern.). From April to November of each year, the canopy arthropods were sampled weekly. PRC method was used to analyse the effect of management regime at the community level and results showed that taxa responded differently to insecticide application suggesting that the organic grove was a more suitable habitat for the arthropods than the integrated protection grove. Abundance of arthropods peaked in May and June for both years but, after spraying with dimethoate, decreased significantly in integrated protection grove, recovering very slowly thereafter. Psocoptera, Miridae, Formicidae and Coccinellidae were the most sensitive taxa to insecticide application. Their decreasing in abundance was more evident in the second year of the trial. On the other hand chrysopids showed some tolerance to insecticide applications. These results suggest that the timing of spray is of utmost importance in reducing the side effects of spraying on beneficial arthropods. Moreover, differences in population susceptibility as well as in life cycle patterns must be considered.
\end{abstract}

(C) 2006 Elsevier Ltd. All rights reserved.

Keywords: Functional groups; Integrated protection; Organic farming; Principal response curves

\section{Introduction}

Olive grove is an agroecosystem that supports a wide range of diverse and functionally important groups of arthropods (Morris et al., 1999; Rodríguez et al., 2003; Ruano et al., 2004). The canopy arthropod community has a complex structure that includes functional groups with phytophagous, predators, parasitoids and detritivores species (Rodríguez et al., 2003; Ruano et al., 2004). The maintenance of the steady state between these groups is

\footnotetext{
* Corresponding author. Tel.: +351 273303371; fax: +351 273325405.

E-mail address: saps@ipb.pt (S.A.P. Santos).
}

important because functional biodiversity performs key ecological services and can bring sustainability to agroecosystem (Altieri, 1999). However, agricultural management practices, specially the use of pesticides, disturb the natural balance between guilds and some phytophagous species increase rapidly resulting in pest outbreaks. These outbreaks of pest populations after chemical treatment may be induced by the reduction of predators or by the development of resistance in pest population to certain insecticides (Marc et al., 1999; Hawkes et al., 2005).

In the last decades, European Union developed policies to regulate pest management under more environmentally sensitive farming practices and has led to a widespread interest in integrated protection (Boller et al., 2004) and 
in organic farming (Council Regulation (EEC) no. 2092/91 of 24 June 1991). Both, integrated protection and organic farming, are management regimes that promote the protection of the environment, specifically biodiversity, soil and water and the achievement of high-quality agricultural products (Guillou and Scharpé, 2000; Malavolta et al., 2002; Boller et al., 2004). To date, insecticides such as, dimethoate, methidathion, phosmet, fenthion, thriclorfon and summer oil (1-2\%), as well as formulations of Bacillus thuringiensis Berliner are allowed in olive groves in integrated pest management in Portugal, although its uses is recommended only when economic threshold is reached, and in some cases in one only application (Gomes and Cavaco, 2003). However, in organic farming only naturally derived pesticides such as $B$. thuringiensis can be used; synthetic pesticides and fertilizers are excluded. Instead of synthetic inputs, compost and animal and green manures are used to build up soil fertility. Biological control through the use of mating disruption, traps and releases of insect predators or parasitoids is especially encouraged for both agricultural systems (Luck et al., 1999).

In integrated protection, the use of authorized chemicals to control olive pests can also affect beneficial arthropods changing the equilibrium of the agroecosystem (Petacchi and Minnocci, 1994; Rodríguez et al., 2003; Ruano et al., 2004). For this, it is essential to improve knowledge on the effects of agricultural practices on arthropod community (pests and beneficial species). Therefore, the objective of this investigation was to study the effect of two different management regimes, organic farming and integrated protection, on canopy arthropod community.

\section{Material and methods}

\subsection{Study areas}

The study areas were located in two olive groves near Mirandela (Portugal), Valbom-dos-Figos and Paradela groves, with different agricultural systems.

Valbom-dos-Figos $\left(41^{\circ} 33^{\prime} 4^{\prime \prime} \mathrm{N}, 7^{\circ} 8^{\prime} 43^{\prime \prime} \mathrm{W}\right)$ grove has been conducted according to organic growing guidelines since 1991. The grove covers an area of 3 ha and was planted with trees between 50 and 80 years old spaced $10 \times 10 \mathrm{~m}$ apart. The predominant cultivars are Cobrançosa and Verdeal Transmontana. No sprays were done against pests or diseases and soil was fertilized with organic nutrients two times a year.

In Paradela $\left(41^{\circ} 32^{\prime} 38^{\prime \prime} \mathrm{N}, 7^{\circ} 7^{\prime} 29^{\prime \prime} \mathrm{W}\right)$ olive grove plant protection was done according to the principles of Integrated Pest Management since 2001. The predominant olive cultivar is Cobrançosa and in low numbers Verdeal Transmontana, Madural and Borrenta. The grove covers an area of $3 \mathrm{ha}$, the planting density is of $9 \times 9$ meters and the trees are about 50 years old. According to farmer's information, a dimethoate spray $\left(150 \mathrm{ml} \mathrm{hl}^{-1}\right.$ of the formulation at $42.8 \%(\mathrm{~W} / \mathrm{V}))$ against the anthophagous generation of the olive moth, Prays oleae (Bern.), was applied in June: 13 and 16 June of 2002 and 2003, respectively; soil was fertilized with organic and mineral nutrients two times a year.

Both olive groves were not irrigated and soil was ploughed superficially with a scarifier two to four times a year to control weeds. Trees were pruned every two or three years. In this work, Valbom-dos-Figos is referred as organic and Paradela as integrated grove.

\subsection{Survey of canopy arthropods}

Sampling was carried out weekly, between April and November of two consecutive years, 2002 and 2003. Arthropods were collected by the beating technique. In every sampling period, five samples per olive grove were collected. Each sample has the beatings of 10 branches randomly selected. All captured individuals were frozen, sorted and identified under binoculars until Orders, Families or species taxa and the total number of each taxon was recorded.

Each taxon was further classified by their trophic role based on personal observation and literature review (Chinery, 1993; Fauvel, 1999; Iperti, 1999; Sommaggio, 1999; Stelzl and Devetak, 1999). Whenever larvae and adults belonged to different functional groups they were counted and classified independently. Phytophagous, predators and detritivores were classified based on whether they ate primarily plants, animals, and dead matter or fungi, respectively. Parasitoids were host feeders; omnivorous had different food sources such as pollen, yeast, fungus, honeydew and small arthropods; and indeterminate included taxa with phytophagous, predators or parasitoids species.

\subsection{Statistical analysis}

Univariate statistical analyses were performed using the Statistica statistical package, version 7.0 (StatSoft, 2004). Data were evaluated for normality and homogeneity of variances with Kolmogorov-Smirnov test and Bartlett's test, respectively and when necessary, the transformation $\log _{10}(x+1)$ was used to normalise the data. The abundance of individuals from different taxa and trophic guilds captured in both olive groves over different times was compared by repeated measures analysis of variance (Zar, 1998).

Multivariate statistical analyses were performed using CANOCO for Windows 4.5 (Ter Braak and Šmilauer, 2002). Multivariate techniques were applied to analyse the response of the whole community. Principal response curves (PRC) analysis is derivative of the multivariate ordination technique redundancy analysis (RDA) and was especially designed for time series obtained from experiments performed with communities (Van den Brink and Ter Braak, 1999; Van den Brink et al., 2003). The resulting PRC diagram displays a curve for the treatment that can be interpreted as the principal response of the community. By definition, the reference is zero in every date and, at each 
sampling period $t$, the deviation (given by a basic response pattern or $C_{d t}$ ) of the treatment curve $d$ compared to reference is proportional to the effect of insecticide spraying. The advantage of this method over other methods is that it is able to focus on the part of the variance explained by the treatment (here integrated grove) when compared with the reference site (here organic grove). The objective of a PRC diagram is to maximize the amount of variance that is displayed by the effect of treatment; when the displayed variances are large then the fitted relative abundance of individual taxa inferred from the diagram matches very well the observed relative abundance (Ter Braak and Smilauer, 2002). The species weight $\left(b_{k}\right)$ indi- cates how closely the response of species $k$ matches the overall community response as displayed in the PRC diagram. Taxa with a positive weight are expected to decrease in abundance, relative to reference while taxa with negative weight are expected to increase. Taxa with species weights between 0.5 and -0.5 show a weak response.

Expression (1) can be applied for each species $k$ at treatment $d$ and sampling date $t$ to evaluate quantitatively the PRC

$\exp \left(b_{k} * C_{d t}\right)$

The value obtained times the geometric mean in the reference gives the abundance in the treatment for species $k$.

Table 1

Total abundance $(N)$ and mean \pm standard error of the mean (SE) of taxa and functional groups captured in total samples in organic and integrated protection olive groves in 2002

\begin{tabular}{|c|c|c|c|c|c|c|c|}
\hline \multirow[t]{2}{*}{ Group } & \multicolumn{2}{|c|}{ Organic $2002(n=145)$} & \multicolumn{2}{|c|}{ Integrated $2002(n=145)$} & \multirow[t]{2}{*}{$F_{1,8}$} & \multirow[t]{2}{*}{$p^{\mathrm{a}}$} & \multirow[t]{2}{*}{$a^{\mathrm{b}}$} \\
\hline & $N$ & Mean $\pm \mathrm{SE}$ & $N$ & Mean $\pm \mathrm{SE}$ & & & \\
\hline \multicolumn{8}{|l|}{ Phytophagous } \\
\hline \multicolumn{8}{|l|}{ Homoptera } \\
\hline E. olivina & 21 & $0.14 \pm 0.03$ & 28 & $0.19 \pm 0.04$ & 0.83 & ns & 2 \\
\hline \multicolumn{8}{|l|}{ Lepidoptera } \\
\hline P. oleae (Larvae) & 14 & $0.10 \pm 0.05$ & 70 & $0.48 \pm 0.12$ & 41.53 & $* * *$ & 2 \\
\hline Thysanoptera & 226 & $1.56 \pm 0.17$ & 264 & $1.82 \pm 0.24$ & 0.07 & ns & 1 \\
\hline \multicolumn{8}{|l|}{ Predators } \\
\hline Araneae & 811 & $5.59 \pm 0.32$ & 495 & $3.41 \pm 0.26$ & 33.49 & $* * *$ & 6 \\
\hline \multicolumn{8}{|l|}{ Heteroptera } \\
\hline Miridae & 382 & $2.63 \pm 0.26$ & 183 & $1.26 \pm 0.23$ & 26.31 & $* * *$ & 10 \\
\hline Anthocoridae & 30 & $0.21 \pm 0.11$ & 10 & $0.07 \pm 0.02$ & 1.75 & $\mathrm{~ns}$ & 1 \\
\hline \multicolumn{8}{|l|}{ Coleoptera } \\
\hline Coccinellidae & 1203 & $8.30 \pm 0.61$ & 530 & $3.66 \pm 0.35$ & 40.30 & $* * *$ & 14 \\
\hline \multicolumn{8}{|l|}{ Neuroptera } \\
\hline Chrysopidae (Larvae) & 57 & $0.39 \pm 0.07$ & 116 & $0.80 \pm 0.10$ & 9.86 & $*$ & 5 \\
\hline \multicolumn{8}{|l|}{ Hymenoptera } \\
\hline Formicidae & 1756 & $12.11 \pm 1.05$ & 2741 & $18.90 \pm 3.29$ & 11.67 & $* *$ & 16 \\
\hline \multicolumn{8}{|l|}{ Parasitoids } \\
\hline Hymenoptera & 728 & $5.02 \pm 0.45$ & 683 & $4.71 \pm 0.48$ & 1.01 & ns & 12 \\
\hline \multicolumn{8}{|l|}{ Detritivores } \\
\hline Dermaptera & 15 & $0.10 \pm 0.03$ & 16 & $0.11 \pm 0.04$ & 0.08 & $\mathrm{~ns}$ & 0 \\
\hline Psocoptera & 1073 & $7.40 \pm 0.63$ & 1037 & $7.15 \pm 1.30$ & 35.98 & $* * *$ & 18 \\
\hline \multicolumn{8}{|l|}{ Omnivorous } \\
\hline Neuroptera & 10 & $0.07 \pm 0.02$ & 4 & $0.03 \pm 0.01$ & 2.79 & ns & 0 \\
\hline Chrysopidae (Adults) & 35 & $0.24 \pm 0.04$ & 39 & $0.27 \pm 0.04$ & 1.14 & ns & 3 \\
\hline \multicolumn{8}{|l|}{ Lepidoptera } \\
\hline P. oleae (Adults) & 58 & $0.40 \pm 0.07$ & 40 & $0.28 \pm 0.06$ & 3.84 & ns & 5 \\
\hline \multicolumn{8}{|l|}{ Indeterminate } \\
\hline Acari & 1805 & $12.45 \pm 2.10$ & 221 & $1.52 \pm 0.30$ & 117.08 & $* * *$ & 21 \\
\hline Coleoptera & 902 & $6.22 \pm 0.43$ & 460 & $3.17 \pm 0.28$ & 36.67 & $* * *$ & 12 \\
\hline Diptera & 941 & $6.49 \pm 0.82$ & 515 & $3.55 \pm 0.55$ & 21.82 & $* *$ & 9 \\
\hline Total & 10067 & $69.87 \pm 3.41$ & 7452 & $51.99 \pm 4.68$ & 30.76 & $* * *$ & 20 \\
\hline \multicolumn{8}{|l|}{ Trophic Guild } \\
\hline Phytophagous & 261 & $2.24 \pm 0.19$ & 362 & $3.10 \pm 0.35$ & 0.83 & $\mathrm{~ns}$ & 5 \\
\hline Predators & 4239 & $29.23 \pm 1.36$ & 4075 & $28.10 \pm 3.44$ & 17.13 & $* *$ & 20 \\
\hline Parasitoids & 728 & $5.02 \pm 0.45$ & 683 & $4.71 \pm 0.48$ & 1.01 & ns & 12 \\
\hline Detritivores & 1088 & $7.50 \pm 0.63$ & 1053 & $7.26 \pm 1.35$ & 32.77 & $* * *$ & 19 \\
\hline Omnivorous & 103 & $0.71 \pm 0.08$ & 83 & $0.57 \pm 0.07$ & 5.21 & $\mathrm{~ns}$ & 4 \\
\hline Indeterminate & 3648 & $25.16 \pm 2.45$ & 1196 & $8.25 \pm 0.74$ & 94.88 & $* * *$ & 16 \\
\hline
\end{tabular}

$n=$ total number of samples.

a $\mathrm{ns}$ - Non-significant, ${ }^{*} p<0.05,{ }^{* *} p<0.01,{ }^{* * *} p<0.001$.

b Number of sample dates (out of 29 total) on which the $F$-value was significant $p<0.05$. 


\section{Results}

A total of 35346 and 14540 arthropods were captured in the organic and integrated groves, respectively over the two years of the study. Arthropods were classified into 12 orders: Acari, Araneae, Coleoptera, Dermaptera, Diptera, Heteroptera, Homoptera, Hymenoptera, Lepidoptera, Neuroptera, Psocoptera and Thysanoptera. From those, five families (Formicidae, Coccinellidae, Miridae, Chrysopidae and Anthocoridae) and two pests were identified, the olive moth $P$. oleae, the most important pest of the olive tree in the region and the olive psylla Euphyllura olivina Costa, a secondary pest. The overall taxa abundance varied between olive groves and years and was significantly higher in organic than in integrated grove $\left(F_{1,8}=30.76\right.$, $p<0.001$ for 2002 and $F_{1,8}=764.26, p<0.001$ for 2003) and in 2003 than in $2002\left(F_{1,548}=46.47, p<0.001\right)$.

In 2002, arthropod community in organic grove was numerically dominated by Acari and Formicidae (17.9\% and $17.4 \%$, respectively), followed by Coccinellidae $(12 \%)$ and Psocoptera (10.6\%); in integrated grove, community was mainly dominated by Formicidae $(36.8 \%)$, followed by Psocoptera (13.9\%). Predators were the most abundant functional group in both groves (Table 1).
Average abundance of seven taxa out of 19 were significantly lower in integrated grove $(p<0.05)$ compared with organic, including predators such as Araneae, Miridae and Coccinellidae. On the other hand, average abundance of Formicidae was significantly higher in integrated than in organic grove but the greatest peaks of abundance were recorded before the application of the insecticide, decreasing thereafter. For phytophagous species, only for the target, $P$. oleae, were found significant differences $(p<$ 0.05 ) between groves with a higher abundance in integrated than in organic grove. No significant differences $(p>0.05)$ were observed for omnivorous and parasitoids between groves (Table 1).

Before sprays against $P$. oleae, the abundance of trophic groups was generally higher in integrated than in organic grove. However, spray caused a decrease in the abundance of arthropods (Fig. 1). Predators and detritivores were the most affected groups. This situation was observed in sampling dates immediately after the insecticide application, when significant differences between groves were found $(p<0.05)$. The effect of spray on detritivores remained until the end of sampling period and no recovery was observed, while parasitoids recovered, increasing in abundance in the mid-summer.
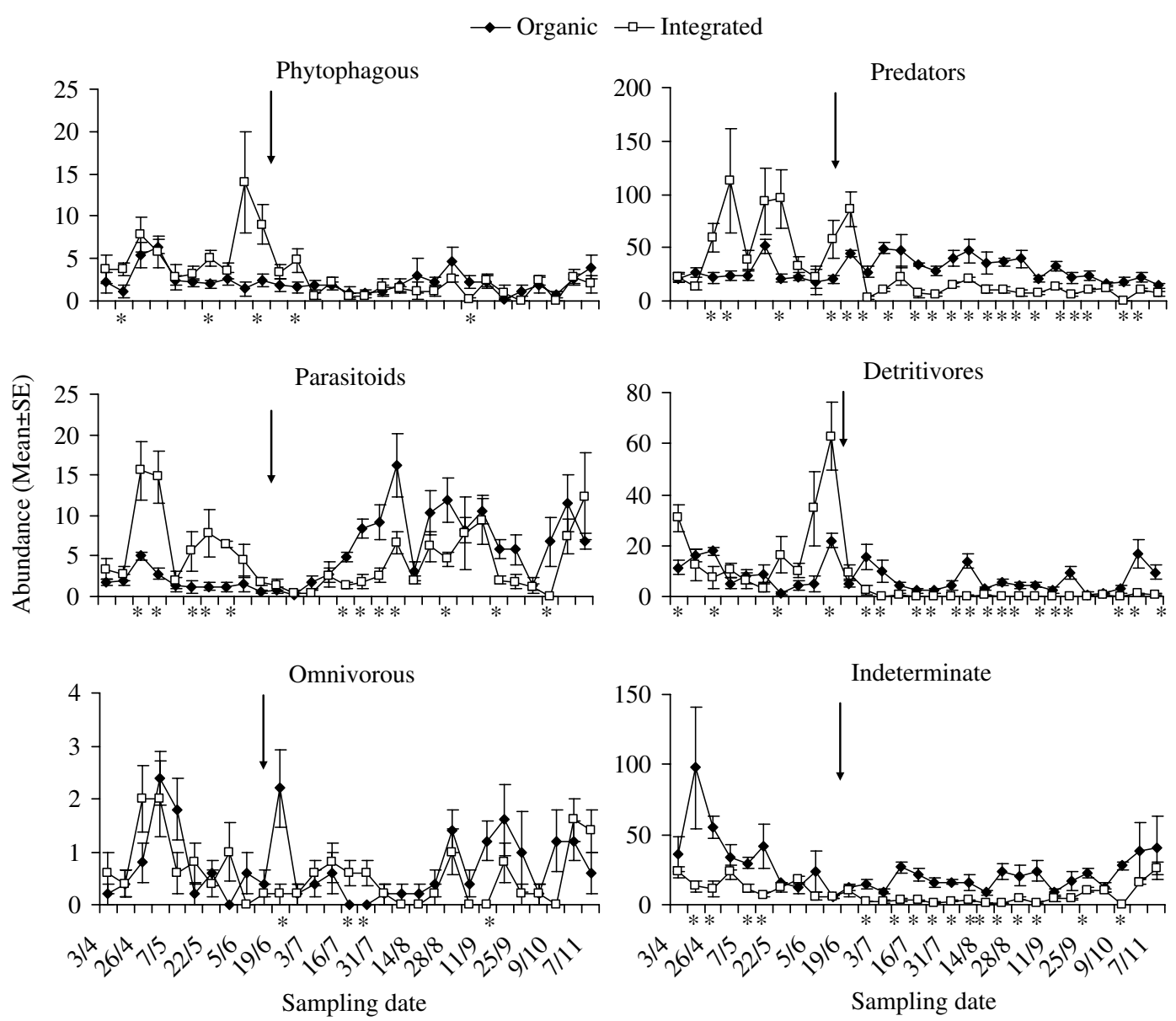

Fig. 1. Abundance (mean $\pm \mathrm{SE}$ ) of different trophic groups in each sampling date during $2002(n=5)$. Asterisks denote dates on which significant differences were observed $(p<0.05)$ between olive groves. Arrows indicate spray date in integrated protection grove. Different axis scales were used. 
In 2003, Psocoptera largely dominated the arthropod community in organic grove with $50.8 \%$ of total specimens captured, followed by Diptera (8.6\%), Coccinellidae (6.9\%) and Formicidae (6.3\%); in integrated grove, Psocoptera accounted $21.9 \%$ of total captures, followed by Diptera $(17.0 \%)$, Araneae $(9.8 \%)$ and Formicidae $(8.8 \%)$. The dominant trophic group was different for organic and integrated groves. Detritivores dominated the former whereas predators prevailed in the second (Table 2). In this year, the differences between management regimes increased. Thus, average abundance of 15 taxa out of 19 was signifi- cantly lower in integrated grove $(p<0.05)$ compared with organic including all phytophagous, predators, parasitoids and indeterminate taxa.

Unlike 2002, during 2003 the seasonal abundance of trophic groups was commonly higher in organic than in integrated grove with the difference being magnified after spraying (Fig. 2). The greatest differences were observed on predators and detritivores which reached high levels of abundance in organic grove in the beginning of summer. In integrated grove the abundance decreased after insecticide application and significant differences between the

Table 2

Total abundance $(N)$ and mean \pm standard error of the mean (SE) of taxa and functional groups captured in total samples in organic and integrated protection olive groves in 2003

\begin{tabular}{|c|c|c|c|c|c|c|c|}
\hline \multirow[t]{2}{*}{ Group } & \multicolumn{2}{|c|}{ Organic $2003(n=130)$} & \multicolumn{2}{|c|}{ Integrated $2003(n=130)$} & \multirow[t]{2}{*}{$F_{1,8}$} & \multirow[t]{2}{*}{$p^{\mathrm{a}}$} & \multirow[t]{2}{*}{$a^{\mathrm{b}}$} \\
\hline & $N$ & Mean \pm SE & $N$ & Mean \pm SE & & & \\
\hline \multicolumn{8}{|l|}{ Phytophagous } \\
\hline \multicolumn{8}{|l|}{ Homoptera } \\
\hline E. olivina & 593 & $4.56 \pm 0.37$ & 238 & $1.83 \pm 0.20$ & 105.86 & $* * *$ & 11 \\
\hline \multicolumn{8}{|l|}{ Lepidoptera } \\
\hline P. oleae (Larvae) & 320 & $2.46 \pm 0.96$ & 191 & $1.47 \pm 0.45$ & 6.59 & $*$ & 3 \\
\hline Thysanoptera & 308 & $2.37 \pm 0.23$ & 246 & $1.89 \pm 0.34$ & 10.41 & ${ }^{*}$ & 9 \\
\hline \multicolumn{8}{|l|}{ Predators } \\
\hline Araneae & 1010 & $7.77 \pm 0.47$ & 696 & $5.35 \pm 0.30$ & 114.79 & $* * *$ & 9 \\
\hline \multicolumn{8}{|l|}{ Heteroptera } \\
\hline Miridae & 1367 & $10.52 \pm 1.46$ & 53 & $0.41 \pm 0.08$ & 306.96 & $* * *$ & 16 \\
\hline Anthocoridae & 80 & $0.62 \pm 0.09$ & 5 & $0.04 \pm 0.02$ & 182.19 & $* * *$ & 4 \\
\hline \multicolumn{8}{|l|}{ Coleoptera } \\
\hline Coccinellidae & 1731 & $13.32 \pm 1.04$ & 332 & $2.55 \pm 0.20$ & 202.91 & $* * *$ & 16 \\
\hline \multicolumn{8}{|l|}{ Neuroptera } \\
\hline Chrysopidae (Larvae) & 326 & $2.51 \pm 0.22$ & 212 & $1.63 \pm 0.17$ & 21.39 & ${ }^{* *}$ & 2 \\
\hline \multicolumn{8}{|l|}{ Hymenoptera } \\
\hline Formicidae & 1584 & $12.18 \pm 0.80$ & 623 & $4.79 \pm 0.81$ & 439.24 & $* * *$ & 16 \\
\hline \multicolumn{8}{|l|}{ Parasitoids } \\
\hline Hymenoptera & 645 & $4.96 \pm 0.36$ & 584 & $4.49 \pm 0.42$ & 14.49 & $* *$ & 10 \\
\hline \multicolumn{8}{|l|}{ Detritivores } \\
\hline Dermaptera & 7 & $0.05 \pm 0.02$ & 48 & $0.37 \pm 0.07$ & 23.49 & $* *$ & 1 \\
\hline Psocoptera & 12840 & $98.77 \pm 10.38$ & 1556 & $11.97 \pm 2.30$ & 1078.20 & $* * *$ & 24 \\
\hline \multicolumn{8}{|l|}{ Omnivorous } \\
\hline Neuroptera & 8 & $0.06 \pm 0.02$ & 20 & $0.15 \pm 0.04$ & 17.11 & $* *$ & 0 \\
\hline Chrysopidae (Adults) & 54 & $0.42 \pm 0.08$ & 43 & $0.33 \pm 0.05$ & 0.31 & ns & 2 \\
\hline \multicolumn{8}{|l|}{ Lepidoptera } \\
\hline P. oleae (Adults) & 495 & $3.81 \pm 0.78$ & 382 & $2.94 \pm 0.91$ & 15.27 & $* *$ & 9 \\
\hline \multicolumn{8}{|l|}{ Indeterminate } \\
\hline Acari & 848 & $6.52 \pm 1.15$ & 70 & $0.54 \pm 0.10$ & 60.48 & $* * *$ & 10 \\
\hline Coleoptera & 878 & $6.75 \pm 0.47$ & 585 & $4.50 \pm 0.33$ & 25.48 & $* * *$ & 12 \\
\hline Diptera & 2185 & $16.81 \pm 2.53$ & 1204 & $9.26 \pm 1.47$ & 80.89 & $* * *$ & 7 \\
\hline Total & 25279 & $195.08 \pm 12.45$ & 7088 & $55.26 \pm 4.93$ & 764.26 & $* * *$ & 22 \\
\hline \multicolumn{8}{|l|}{ Trophic Guild } \\
\hline Phytophagous & 1221 & $10.02 \pm 1.24$ & 675 & $5.93 \pm 0.81$ & 37.41 & $* * *$ & 12 \\
\hline Predators & 6098 & $46.91 \pm 3.05$ & 1921 & $14.78 \pm 1.01$ & 553.28 & $* * *$ & 18 \\
\hline Parasitoids & 645 & $4.96 \pm 0.38$ & 584 & $4.49 \pm 0.45$ & 14.49 & $* *$ & 10 \\
\hline Detritivores & 12847 & $98.82 \pm 10.96$ & 1604 & $12.34 \pm 2.45$ & 932.29 & $* * *$ & 24 \\
\hline Omnivorous & 557 & $4.28 \pm 0.82$ & 445 & $3.42 \pm 0.97$ & 8.83 & $*$ & 5 \\
\hline Indeterminate & 3911 & $30.08 \pm 3.17$ & 1859 & $14.30 \pm 1.62$ & 150.50 & $* * *$ & 15 \\
\hline
\end{tabular}

$n=$ total number of samples.

a ns - Non-significant, ${ }^{*} p<0.05,{ }^{* *} p<0.01,{ }^{* * *} p<0.001$.

${ }^{\mathrm{b}}$ Number of sample dates (out of 26 total) on which the $F$-value was significant $p<0.05$. 
two groves were found in 15 out of 17 sampling dates for predators and 16 out of 17 dates for detritivores. Once more, parasitoids recovered easily after spraying.

Phytophagous were much more abundant in 2003 than in 2002 and it happened that in both years, sprays were done after the peak value of abundance has been reached.

PRC diagram concisely shows changes through the two years in the variability of canopy arthropod community composition. Of the total variance, $43 \%$ is explained by sampling date and $29 \%$ by management regime. The Monte Carlo permutation test showed a significant difference between groves and $63 \%$ of that difference is displayed by the first PRC axis (Fig. 3). On the sampling dates immediately before each insecticide application, PRC shows small differences between the integrated and organic curves indicating that captures were similar. After that, PRC shows large differences and the negative values of $c d t$ indicate that captures were lower in the treatment than in reference; the greatest differences in catch between groves are clearly evident in two periods: 19 June 2002 and 17 June 2003 which coincides with sprays against $P$. oleae. After insecticide applications the arthropod community recovered very slowly. Psocoptera had the highest positive weight $\left(b_{k}\right)$ followed by important predators groups such as Miridae, Coccinellidae (adults) and Formicidae that decreased in abundance after insecticide application. Taxa with weights between -0.5 and 0.5 , like $P$. oleae (larvae), had a weak contribution to the overall community response. Expression (1) was applied to the two groups of predators most affected by the spraying. Thus, for abundance of mirids on 25 June 2002, the PRC diagram predicts that at integrated grove it would be $\exp (1.6 *-0.75)=0.30$ times the abundance at organic grove. For coccinellids, the fitted relative difference in abundance between organic and integrated groves on 25 June 2002 is $\exp (1.47 *-0.75)=$ 0.33 . This agrees well with the actual data, in which the geometric mean counts on 25 June 2002 for mirids were 0.8 and 2.5, respectively, for integrated and organic groves (relative abundance 0.32) and for coccinellids were 1.1 and 3.0 (relative abundance 0.37). Similarly, on 25 June 2003, the PRC diagram predicts that the abundance of Mirids in integrated grove would be $\exp (1.60 *-1.75)=0.06$ times that observed in organic grove. For coccinellids the difference in abundance between both olive groves is $\exp (1.47 *-1.75)=0.076$. Again, in this example, the fitted relative abundance is close to the observed relative abundance of 0.057 for mirids (geometric mean counts were 2.4 and 41.9 , respectively, for integrated and organic grove) and 0.074 for coccinellids (geometric mean counts were 2.2 and 29.4, respectively, for integrated and organic grove).



$\rightarrow$ Integrated
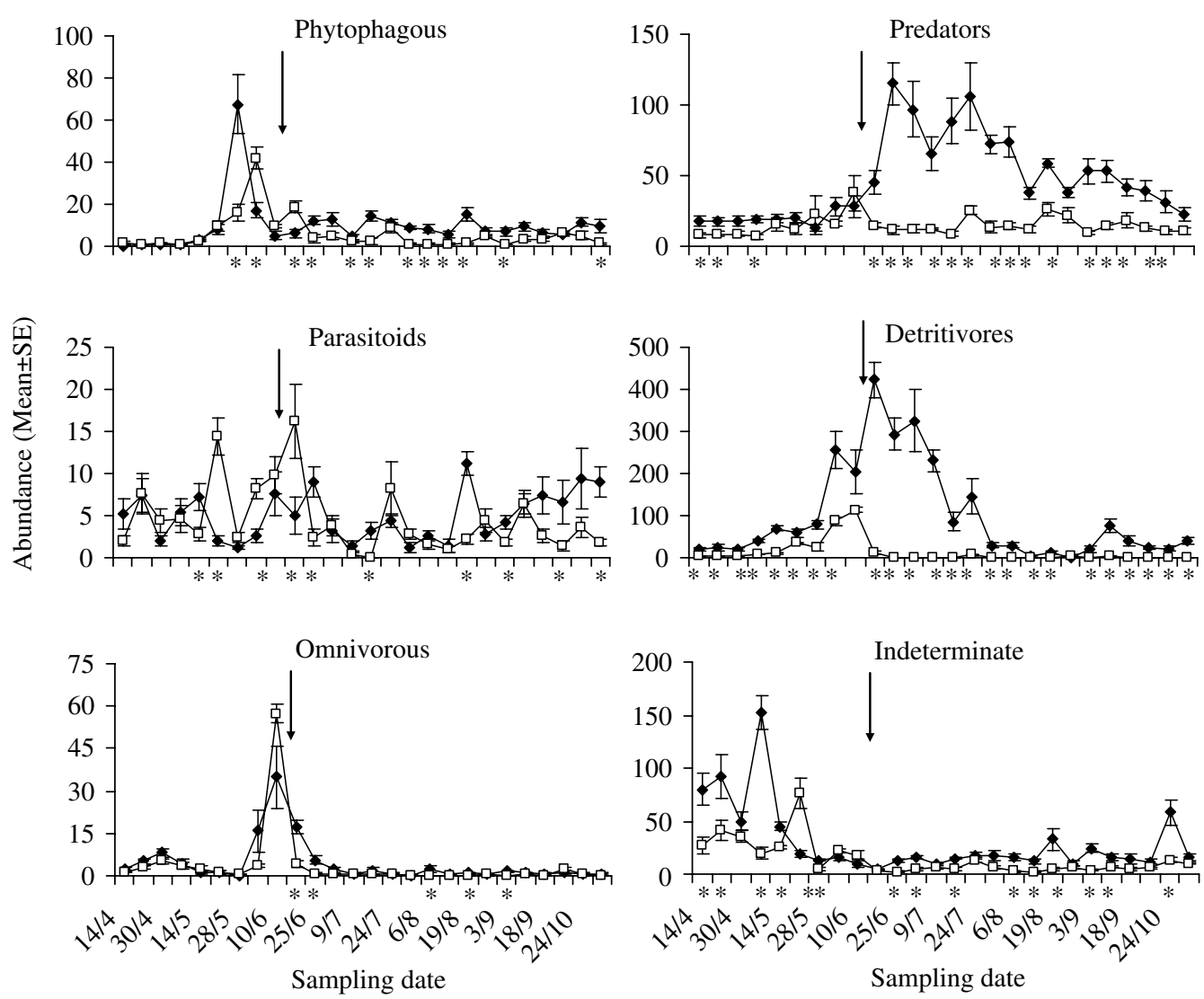

Fig. 2. Abundance (mean $\pm \mathrm{SE}$ ) of different trophic groups in each sampling date during $2003(n=5)$. Asterisks denote dates on which significant differences were observed $(p<0.05)$ between olive groves. Arrows indicate spray date in integrated protection grove. Different axis scales were used. 

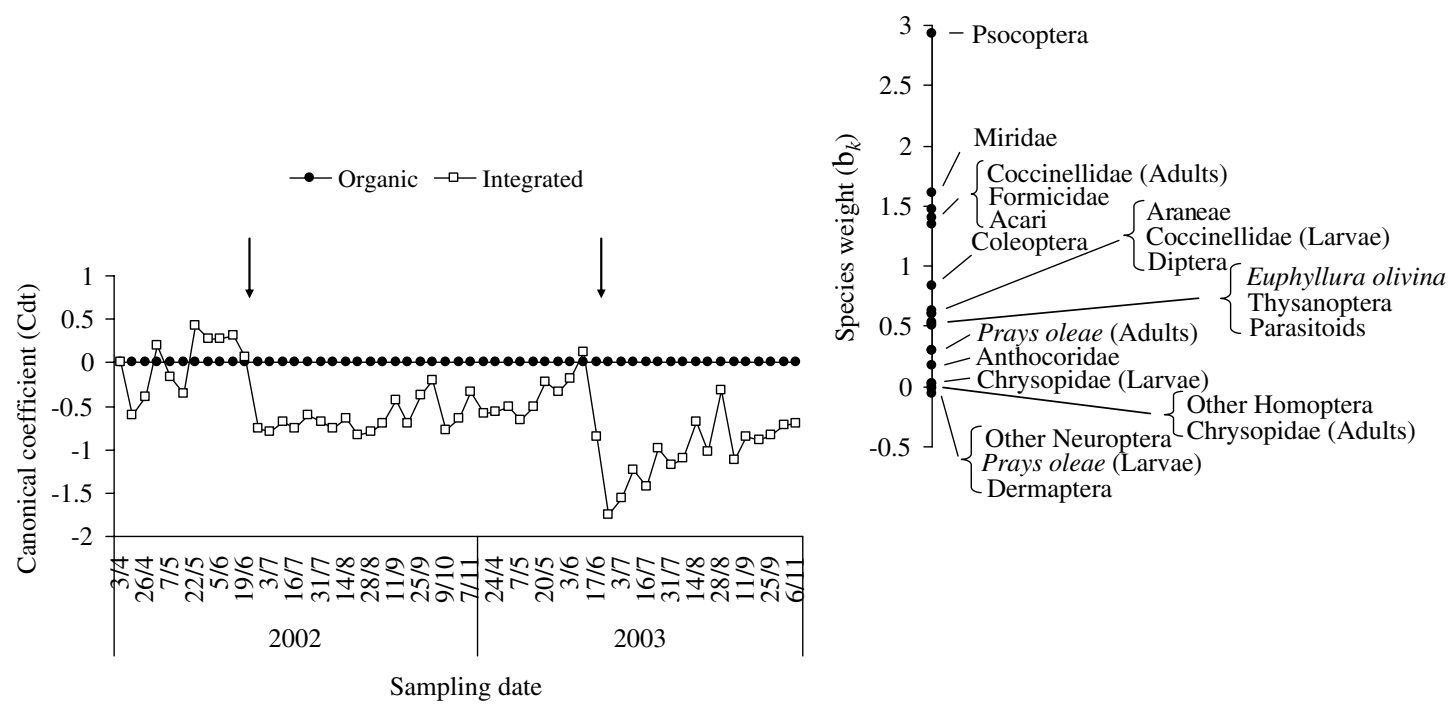

Fig. 3. PRC diagram and species weights for sampled arthropods, showing variation in taxa abundance during two years of study. Arrows indicate spray date in integrated protection grove.

\section{Discussion}

In this study, the most representative orders were Psocoptera, Hymenoptera, Diptera and Coleoptera varying in proportion between groves and years. These groups have been reported in the literature (Petacchi and Minnocci, 1994; Belcari and Dagnino, 1995; Ruano et al., 2001) as typically abundant groups in olive groves. Psocoptera is considered an unimportant economically order (Chinery, 1993) whereas the other three orders include key-groups of predators, parasitoids and phytophagous. Ants and wasps (O. Hymenoptera) and coccinellids (O. Coleoptera), for instance, play an important role in the biological control of olive pests like P. oleae and Saissetia oleae (Olivier) (Obrycky and Kring, 1998; Iperti, 1999; Morris et al., 1999, 2004).

In the two years of study, total abundance was higher in organic than in integrated olive grove. However, Ruano et al. (2004) found a higher total abundance of arthropods in integrated than in organic grove as a consequence of the number of Homoptera, namely due to the presence of the olive pest E. olivina.

Disturbance caused by the use of dimethoate to control anthophagous generation of $P$. oleae in integrated grove had a strong and dramatic effect on the abundance of different trophic groups. Predators and detritivores, in particular, showed a long recovery period. Petacchi and Minnocci (1994) using chromotropic sticky traps and Belcari and Dagnino (1995) using Malaise traps also observed an abrupt reduction of entomofauna in Italian olive groves after dimethoate application.

PRC showed that the target species, P. oleae, was not strongly affected by insecticide treatments, probably because these were not correctly timed as in both years they were done slightly after the abundance of anthophagous generation has reached its peak. As a consequence of successive applications of dimethoate, is likely that the pest population has developed insecticide resistance, similarly to what was demonstrated for another pest, the olive fruit fly, Bactrocera oleae (Gmelin) (Hawkes et al., 2005).

Mirids, coccinellids and ants were the predators more affected by the insecticide, which in part can be explained by the fact that they were abundant groups when sprays were done. The effect of insecticide was even more pronounced in 2003 because the abundance of those groups reached higher values than in 2002. Rodríguez et al. (2003) also found a strong toxicity of the deltamethrin towards those families. Fauvel (1999) stated that mirids are rather susceptible to insecticides and are eliminated from commercial groves because of low number of generations per year. Comparatively, anthocorids are more tolerant to pesticide application being better able to maintain themselves in the presence of chemical treatments in part due to the occurrence of a greater number of generations per year and because they are more mobiles having great ability to search for protection (Fauvel, 1999). However, anthocorids are typically found in minor number than mirids in olive cultivation and in this study they were found in more abundance in the organic grove.

Iperti (1999) verified that coccinellids are, in general, highly vulnerable toward chemical treatments and dimethoate is considered a very toxic insecticide to this predaceous group. In laboratory studies, Ba M'hamed and Chemseddine (2002) concluded that Pullus mediterraneus is a very sensitive species to dimethoate. These authors observed high mortality rates of adults within few hours after dimethoate exposition at recommended doses. $P$. mediterraneus was a common species in both organic and integrated olive groves (Santos et al., unpublished). 
Although ants are considered a key-group in olive grove (Morris et al., 1999; Pereira et al., 2004) namely as bioindicators of disturbances, the information concerning the effect of pesticides over this group is scarce. In olive grove, ant species nest in soil or in old olive trunks and climb to the canopy to eat insects and liquid sugars (Redolfi et al., 1999). Two ideas can be addressed to justify the decrease of ants in integrated grove. On the one hand, ants could be a susceptible group and were directly affected by the spray with dimethoate. On the other hand, prey depletion on the canopy justifies the consequently decrease of these predators that stop to climb the tree staying in the soil.

Spiders are abundant predators in olive groves, but their role is relatively unknown. They were more abundant in organic than in integrated grove indicating some susceptibility to chemicals. This result is in agreement with those obtained by Ruano et al. (2004) and Cárdenas et al. (2006). In tomato fields, Yardim and Edwards (1998) also observed a severe decrease of spider populations after treatments with carbaryl, endosulfan and esfenvalerate insecticides although different species respond in different ways when exposed to pesticide residues.

Parasitoids, showed a good recovery rate after spraying probably because at the time of treatment they were protected inside the insect host being less exposed to the insecticide. However, considering the individuals affected, it is difficult to make the distinction whether parasitoids larvae died directly or because their hosts were killed by the insecticide.

Chrysopids showed to be the more tolerant predators to insecticide since their species weight in PRC diagram is next to zero. In addition, several authors reported the tolerance of chrysopids to certain insecticides. In the study of Rodríguez et al. (2003), chrysopids, namely the most abundant species in olive grove, Chrysoperla carnea Stephens, showed some resistance to deltamethrin. Furthermore, Ruano et al. (2001) using the beating technique and Corrales and Campos (2004) using McPhail traps caught more chrysopids in integrated groves treated with dimethoate than in organic olive groves, as occurred in our study in 2002. Stelzl and Devetak (1999) considered that, due to their voracity and tolerance to many insecticides, chrysopids (especially C. carnea) seems to show all the biological and ecological attributes for mass production. Therefore, mass rearing and mass release of chrysopids should become standard methods of biological pest control.

For less abundant groups such as Dermaptera and other Neuroptera, the PRC output should be regarded with caution since abundance of those groups was very low, the impact of insecticide application may be misleading. Although according to PRC diagram they can be classified as tolerant groups more studies are needed to support this idea.

In sum, PRC method showed to be a valuable tool for evaluating effects of management regime at the community level although for groups with few sampled individuals, results must be carefully considered; otherwise the conclusions can be biased.

\section{Conclusions}

The olive management regime influenced the patterns of abundance of arthropod community. The abundance of different trophic groups was reduced after the application of dimethoate to control $P$. oleae in integrated grove. The impact of the pesticide was more pronounced on predaceous mirids, coccinellids and ants. Besides the intrinsic susceptibility of each group, the pattern of the life cycle and the number of generations per year are also ecological characteristics that influence the effect of the insecticide and the capacity to recover.

This study suggested that a timely application will be more effective in the control of the pest. Therefore, some attempt must be done in order to choose the most suitable occasion to do the application allowing also the reduction of the dose of pesticide applied. A more effective control of olive pests can be achieved by increasing the cooperation between farmers, technicians and researchers. The idea is to apply the best management practices in order to reduce negative impacts on biodiversity that provides ecological services such as biological pest control. These services promote the sustainability of agroecosystems and enhance nutrient cycling, and water and soil conservation.

\section{Acknowledgements}

The authors thank Dr. Paul J. Van den Brink for his advice on multivariate analysis. This study was founded by projects - AGRO 236 "Protecção contra pragas em olivicultura biológica" and AGRO 482 "Protecção contra pragas do olival numa óptica de defesa do ambiente e do consumidor".

\section{References}

Altieri, M.A., 1999. The ecological role of biodiversity in agroecosystems. Agr. Ecosyst. Environ. 74, 19-31.

Ba M'hamed, T., Chemseddine, M., 2002. Selective toxicity of some pesticides to Pullus mediterraneus Fabr. (Coleoptera: Coccinellidae), a predator of Saissetia oleae Bern. (Homoptera: Coccoidea). Agr. Forest. Entomol. 4, 173-178.

Belcari, A., Dagnino, A., 1995. Preliminary study of the insects caught by a "malaise" trap in an olive grove in northern Tuscany. Agr. Mediterranica 125, 184-192.

Boller, E.F., Avilla, J., Joerg, E., Malavolta, C., Wijnands F.G., Esbjerg P., 2004. Integrated Production. Principles and Technical Guidelines, third ed. OILB/WPRS Bulletin, vol. 27, 54pp.

Cárdenas, M., Ruano, F., García, P., Pascual, F., Campos, M., 2006. Impact of agricultural management on spider populations in the canopy of olive trees. Biol. Control. 38, 188-195.

Chinery, M., 1993. Insects of Britain and Northern Europe, third ed. Collins Publishers, London, UK.

Corrales, N., Campos, M., 2004. Populations, longevity, mortality and fecundity of Chrysoperla carnea (Neuroptera, Chrysopidae) from olive-orchards with different agricultural management systems. Chemosphere 57, 1613-1619. 
Fauvel, G., 1999. Diversity of Heteroptera in agroecosystems: role of sustainability and bioindication. Agr. Ecosyst. Environ. 74, 275-303.

Gomes, H.B., Cavaco, M., 2003. Protecção Integrada da Oliveira - Lista dos Produtos Fitofarmacêuticos e Níveis Económicos de Ataque. Ministério da Agricultura, Desenvolvimento Rural e Pescas - Direcção Geral de Protecção das Culturas, Oeiras, Portugal, 55pp.

Guillou, G., Scharpé, A., 2000. Organic Farming. Guide to Community Rules. Office for Official Publications of the European Communities, Luxemburg, 28pp.

Hawkes, N.J., Janes, R.W., Hemingway, J., Vontas, J., 2005. Detection of resistance-associated point mutations of organophosphate-insensitive acetylcholinesterase in the olive fruit fly, Bactrocera oleae (Gmelin). Pest Biochem. Physiol. 81, 154-163.

Iperti, G., 1999. Biodiversity of predaceous coccinellidae in relation to bioindication and economic importance. Agr. Ecosyst. Environ. 74, 323-342.

Luck, R.F., Shepard, B.M., Kenmore, P.E., 1999. Evaluation of biological control with experimental methods. In: Bellows, T.S., Fisher, T.W. (Eds.), Handbook of Biological Control. Academic Press, San Diego, USA, pp. 225-242.

Malavolta, C., Delrio, G., Boller, E.F., 2002. IOBC Technical Guidelines III. Guidelines for the integrated production of olives. IOBC/WPRS Bull. 25, 1-8.

Marc, P., Canard, A., Ysnel, F., 1999. Spiders (Araneae) useful for pest limitation and bioindication. Agr. Ecosyst. Environ. 74, 229-273.

Morris, T.I., Campos, M., Kidd, N.A.C., Jervis, M.A., Symondson, W.O.C., 1999. Dynamics of the predatory arthropod community in Spanish olive groves. Agr. Forest. Entomol. 1, 219-228.

Morris, T.I., Symondson, W.O.C., Kidd, N.A.C., Campos, M., 2004. The effect of different ant species on the olive moth, Prays oleae (Bern.), in Spanish olive orchard. J. Appl. Entomol. 126, 224-230.

Obrycky, J.J., Kring, T.J., 1998. Predaceous coccinellidae in biological control. Annu. Rev. Entomol. 43, 295-321.

Pereira, J.A., Bento, A., Cabanas, J.E., Torres, L.M., Herz, A., Hassan, S.A., 2004. Ants as predators of the egg parasitoid Trichogramma cacoeciae (Hymenoptera: Trichogrammatidae) applied for biological control of the olive moth, Prays oleae (Lepidoptera: Plutellidae) in Portugal. Biocontrol Sci. Techn. 14, 653-664.
Petacchi, R., Minnocci, A., 1994. Impact of different Bactrocera oleae (Gmel) control strategies on olive-grove entomofauna. Acta Horticulturae 356, 399-402.

Redolfi, I., Tinaut, A., Pascual, F., Campos, M., 1999. Qualitative aspects of myrmecocenosis (Hym., Formicidae) in olive orchards with different agricultural management in Spain. J. Appl. Ent. 123, 621-627.

Rodríguez, E., Peña, A., Sánchez Raya, A.J., Campos, M., 2003. Evaluation on the effect on arthropod populations by using deltamethrin to control Phloeotribus scarabaeoides Bern. (Coleoptera: Scolytidae) in olive orchards. Chemosphere 52, 127-134.

Ruano, F., Lozano, C., Tinaut, A., Peña, A., Pascual, F., García, P., Campos, M., 2001. Impact of pesticides on beneficial arthropod fauna in olive orchards. Bull. OILB/SROP 24, 113-120.

Ruano, F., Lozano, C., Garcia, P., Peña, A., Tinaut, A., Pascual, F., 2004. Use of arthropods for the evaluation of the olive-orchard management regimes. Agr. Forest Entomol. 6, 111-120.

Sommaggio, D., 1999. Syrphidae: can they be used as environmental bioindicators? Agr. Ecosyst. Environ. 74, 343-356.

StatSoft, Inc., 2004. STATISTICA (data analysis software system), version 7. <www.statsoft.com>.

Stelzl, M., Devetak, D., 1999. Neuroptera in agricultural ecosystems. Agr. Ecosyst. Environ. 74, 305-321.

Ter Braak, C.J.F., Šmilauer, P., 2002. CANOCO reference manual and user's guide to Canoco for Windows: software for canonical community ordination (version 4.5). Microcomputer Power, Ithaca, New York.

Van den Brink, P.J., Ter Braak, C.J.F., 1999. Principal Response Curves: analysis of time-dependence multivariate responses of biological community to stress. Environ. Toxicol. Chem. 18, 138-148.

Van den Brink, P.J., Van den Brink, N.W., Ter Braak, C.J.F., 2003. Multivariate analysis of ecotoxicological data using ordination: demonstrations of utility on the basis of various examples. Australas. J. Ecotox. 9, 141-156.

Yardim, E.N., Edwards, C.A., 1998. The influence of chemical management of pests, diseases and weeds on pest and predatory arthropods associated with tomatoes. Agr. Ecosyst. Environ. 70, 31-48.

Zar, J.H., 1998. Biostatistical Analysis, fourth ed. Prentice Hall, London, UK. 